\title{
Analiza pastoralnih nastojanja nakon proglašenja dokumenta Ti si Krist - za nas i za sve ljude. Izjave i odluke Druge biskupijske sinode đakovačke i srijemske
}

\author{
STANISLAV ŠOTA* \\ • https://doi.org/10.31823/d.27.1.3 • \\ UDK: 2-46-733(497.5 Đakovo) • Pregledni članak \\ Primljeno: 10. srpnja 2018. • Prihvaćeno: 12. ožujka 2019.
}

${ }^{*}$ Doc. dr. sc. Stanislav Šota, Katolički bogoslovni fakultet u Đakovu

Sveučilišta J. J. Strossmayera u Osijeku, P. Preradovića 17, p. p. 54, 31400 Đakovo, Hrvatska, stanislav. sota@os.t-com.hr

Sažetak: Crkva đakovačka i srijemska biskupija nakon prvih demokratskih izbora, poslije četrdeset i pet godina totalitarnoga komunističkoga režima te tijekom Domovinskoga rata $i$ velikosrpske agresije 90-ih godina prošloga stoljeća uvelike je promijenila svoje lice i naličje, okolnosti i ambijent. Druga sinoda bila je dogadaj i dogadanje Duha Svetoga i konkretnoga čovjeka. Odluke, izjave i odredbe biskupijske sinode trebale su postati svakodnevni život partikularne Crkve. Godine 2008. objavljena je Knjiga sinode Ti si Krist - za nas i za sve ljude. Deset godina nakon objavljivanja Izjava i odluka Druge biskupijske sinode đakovačke i srijemske osvrtom na pastoralna nastojanja kroz jedno desetljeće uočava se kako su Izjave i odluke Druge biskupijske sinode đakovačke i srijemske $u$ većoj mjeri zaživjele tek u 30 \% župnih zajednica Đakovačkoosječke nadbiskupije. Kriza evangelizacijskoga žara prezbitera, svećenika, župnika, krize njegova identiteta, formacije koja je u velikoj mjeri ignorirala sinodske zaključke, komunističko nasljeđe s posljedicama vjerskoga indiferentizma, nesuživljenost s Crkvom, klerikalizmom, pasivnost, posebice današnja kultura izbora i diktatura relativizma temeljni su i najčešći uzroci što dokument Ti si Krist- za nas i za sve ljude nije magna carta pastoralnoga djelovanja Đakovačko-osječke nadbiskupije. Analiza pastoralnih nastojanja ukazuje na potrebu veće stručnosti $i$ osposobljenosti, napose profesionalizacije $i$ specijalizacije voditelja ureda, povjerenika i osoba kojima je 
povjereno jedno od pastoralnih područja. Velika većina voditelja ureda, povjerenika i tajnika uz jednu ili nekoliko drugih službi povjereno područje nastoji ostvariti bez dovoljno mogućnosti da se kvalitetno angažira. Uočava se veća i snažnija potreba uključivanja vjernika laika u vođenje pojedinih ureda i povjerenstava. Ako mjesna Crkva želi snažnije implementirati sinodske dokumente u svakodnevni život, mora smoći snage uključiti vjernike laike u pastoralni život i rad Nadbiskupije. Potrebna je snažna promjena pastoralnoga pristupa, načina i metoda u pastoralnom radu i djelovanju. Sinoda je postala više događaj, a željelo se da postane sustavno događanje. Snaga »plamenih jezika « (usp. Iz 5, 24) pretvorila se ili ostala »stijenje što tek tinja (usp. Iz 42, 3; Mt 12, 20). Crkvi đakovačko-osječkoj potrebni su sustavni, snažno infrastrukturalno profesionalizirani, isusovsko hrabri iskoraci. Unatoč poteškoćama i nedostacima Đakovačko-osječka nadbiskupija i njezin život nezamislivi su bez sinodskih dokumenta, odnosno Izjava i odluka Druge biskupijske sinode đakovačke i srijemske.

Ključne riječi: Druga biskupijska sinoda đakovačka i srijemska, sinoda, analiza, pastoralni uspjesi i neuspjesi, potreb a promjene.

\section{Uvod}

$\gg$...Duh Sveti i mi odlučili smo ne stavljati na vas nikakva drugog tereta osim ovih potrebnih stvari...« (Dj 15, 28). Tako apostoli pišu prvim Crkvama nakon Sabora u Jeruzalemu svjesni kako Duh Sveti prosvjetljuje, vodi, potiče i usmjerava prema rješavanju novonastalih teoloških, eklezijalnih i pastoralnih poteškoća i problema u Crkvi. Sabor kao događaj Crkve na zemlji u sebi sadržava dvije temeljne postavke i oznake svih budućih sabora (na razini opće Crkve) i biskupijskih sinoda (mjesnih Crkava): djelovanje Duha Svetoga i suradnja čovjeka vjernika obilježenoga vlastitim specifičnostima, posebnostima i okruženjem na društvenoj, kulturnoj, teološkoj, moralnoj razini i značenju. ${ }^{1}$ Ikonografija zaključaka općih sabora i biskupijskih sinoda sjaj i odsjaj su neba i zemlje određenoga konkretnoga povijesnoga trenutka. ${ }^{2}$ $\mathrm{Na} C r k v u$, bilo opću bilo partikularnu, utječu i obilježavaju je unutarnji i vanjski događaji i okolnosti, posebice unutarnja i vanjska kretanja. Sinoda mjesne Crkve na taj način mora biti i jest događaj i događanje Duha Svetoga i konkretnoga čovjeka. Odluke, izjave i odredbe biskupijskih sinoda u tom smislu nisu samo smjernice $s$ dobro uređenim i sročenim rečenicama, nego one moraju postati i svakodnevni život partikularne ili mjesne Crkve, i to polazeći od konkretnoga stanja suvremenoga čovjeka. Sinodski zaključci biskupijskih sinoda stoga trebaju pronaći put do srca svakoga vjernika partikularne Crkve. Partikularna Crkva uz snagu Duha Svetoga i milost Božju mora imati snage i svjetla mijenjati se, rasti i uhvatiti u koštac $s$

${ }^{1}$ Usp. M. ŠKVORC, Jeruzalem ili Antiohija, Zagreb, 1988., 171.

${ }^{2}$ Y. CONGAR, Le concile et les conciles, Chevetogene, 1960., 319., u: M. ŠKVORC, Jeruzalem ili Antiohija, 171. 
izazovima evangelizacijske, pastoralne i katehetske naravi. Đakovačka i srijemska Crkva tijekom Domovinskoga rata i velikosrpske agresije 90-ih godina prošloga stoljeća uvelike je promijenila svoju fizionomiju, okolnosti i ambijent. Velikosrpskom agresijom ranjena je na duši i tijelu. ${ }^{3}$ Mnoge su župe tijekom rata opustjele i materijalno i duhovno, mnogi su vjernici zbog velikosrpske agresije i politike bili primorani napustiti dom. Jedan dio vjernika nakon mirne reintegracije 15. siječnja 1998. godine nije se nakon progonstva vratio kućama. Srijemska biskupija također je osmišljenom velikosrpskom agresijom raseljena, a njezino stanovništvo protjerano. ${ }^{4} \mathrm{U}$ takvim okolnostima đakovački i srijemski biskup mons. dr. Marin Srakić 1996. godine najavio je sazivanje Druge biskupijske sinode đakovačke i srijemske. U prvom dijelu rada analizira se društveno-crkveni kontekst sazivanja Druge biskupijske sinode đakovacke i srijemske. Drugi dio rada prikazuje tijek sinodskih događanja, a treći dio kritički analizira njezino ostvarenje kroz posljednjih deset godina života mjesne Crkve đakovačko-osječke.

\section{Društveni i crkveni kontekst sazivanja Druge biskupijske sinode dakovačke i srijemske}

Društveni i crkveni kontekst sazivanja Druge biskupijske sinode đakovačke i srijemske biskupije potrebno je promatrati kroz dvije stvarnosti, događaje koji su u velikoj mjeri utjecali na njezin život, rad, fizionomiju, na pastoralno i katehetsko djelovanje. Komunizam i komunistička ideologija kroz pedeset godina nastojala je Crkvu u Hrvata, a time i u Đakovačkoj i Srijemskoj biskupiji, stjerati u sakristiju, getoizirati, onemogućiti njezin život i rad. ${ }^{5}$ Međutim Crkva u Hrvata i u otežanim okolnostima pokazala je kako i u takvim okolnostima može ostvarivati i ispunjavati temeljnu zadaću evangeliziranja i katehiziranja. Demokratskim promjenama u Republici Hrvatskoj Crkvi su se otvorile nove, velike, mnogobrojne i različite mogućnosti pastoralnoga i katehetskoga djelovanja. No vrlo brzo uslijedila je velikosrpska agresija koja je kao i komunizam u velikoj mjeri ostavila posljedice, posebice usporila te djelomično i onemogućila evangelizacijski zamah koji se Crkvi tada pružao.

\subsection{Pastoralno i katehetsko djelovanje Crkve u Đakovačkoj i SRIJEMSKOJ BISKUPIJI U VRIJEME KOMUNISTIČKE JUGOSLAVIJE}

Sveobuhvatni pastoralni plan i program te nova evangelizacija konstitutivni su dijelovi pastoralnoga planiranja, napose djelovanja opće i partikularne Crkve. ${ }^{6}$ Ana-

\footnotetext{
${ }^{3}$ Usp. V. GRUDEN, Ožiljci na duši Hrvatske, Zagreb, 1996., 215-225.

${ }^{4}$ Usp. M. BIČANIĆ, Srijem krvavo krilo Hrvatske, Zagreb, 1994., 175-359.

${ }^{5}$ Usp. J. BALOBAN, Djelovanje Crkve u novim društvenim okolnostima, Zagreb, 1995., 7-10.

${ }^{6}$ Usp. isto, 7.
} 
lizirajući pastoralno djelovanje Crkve u Hrvata, imajući u ovom kontekstu pred sobom posebno Đakovačku i Srijemsku biskupiju, potrebno je uzeti u obzir društvene prilike i okolnosti kao osnovno polazište za mogućnosti i ostvarenja poslanja Crkve. Dolaskom komunizma na vlast 1945 . godine u Jugoslaviji nastupilo je vrijeme progona Crkve jer su marksizam, lenjinizam i komunizam ideologije kojima je u temelju ateizam. ${ }^{7} \mathrm{Za}$ sve Crkve u kojima je vladao komunizam u zapadnom dijelu Europe govorilo se o $\gg$ Crkvi šutnje «, $\gg$ Crkvi iza željezne zavjese «, $\gg$ Crkvi u progonstvu $\ll{ }^{8} \mathrm{U}$ komunističkoj Jugoslaviji $\gg$ jednopartijski sustav sprječavao je svaki vid demokracije. Institucije koje su se ideološki, politički ili idejno razlikovale od komunističke ideologije bile su uklanjane ili stavljane na marginu društva... Represija je bila osnovno sredstvo provođenja i čuvanja ideologije Komunističke partije, a obuhvaćala je različite oblike, od psihičke, javne, osobne, političke, kulturne, znanstvene do fizičke represije $\ll .{ }^{9}$ Crkva je tada bila jedna od rijetkih institucija koja je dijelila sudbinu svoga naroda i bila s njim tijesno povezana. Zbog toga je Crkva za komunističke ideologe bila neprijatelj naroda i države. Pokušalo se odvojiti Katoličku Crkvu od Rima i stvoriti nacionalnu državnu Crkvu. Nastojalo se marginalizirati značenje i utjecaj Katoličke Crkve u narodu, obezvrijediti, relativizirati evangelizacijsko, pastoralno i katehetsko poslanje te ga svesti na minimum. Različitim represivnim metodama vjerske slobode i pravo na slobodu vjeroispovijesti svedeni su na minimum. Uz ubojstva svećenika, progone i montirana suđenja svećenicima i biskupima, progon časnih sestara iz bolnica, staračkih i učeničkih domova, Crkvi je 1952. godine u potpunosti zabranjena vjerska pouka u školi te djelomično i u crkvi. ${ }^{10}$ Unatoč svemu Crkva u Jugoslaviji, a time i u Đakovačkoj i Srijemskoj biskupiji, tražila je mogućnosti evangelizacije i katehizacije. Dekanatske konferencije imale su veoma važnu ulogu u svećeničkom praćenju te promišljanju pastoralnih i katehetskih organizacijskih struktura i modela. Uključivanje časnih sestara u službu katehistica od 1951. godine, pokretanje katehetskih tečajeva za časne sestre 1956. godine i osnivanje katehetske škole u Đakovu 1958. godine, potom nekoliko godina kasnije u Zagrebu, najprovidnosniji su i ključni koraci na području župne kateheze, ne samo u Đakovačkoj i Srijemskoj biskupiji već i cijeloj komunističkoj Jugoslaviji. Uključivanje časnih sestara u župnu katehezu u vrijeme komunizma uvelike je promijenilo način i kvalitetu pastoralnoga i katehetskoga rada Katoličke Crkve u Jugoslaviji. ${ }^{11}$ Naputak biskupske konferencije Jugoslavije Radosno naviještanje Evandelja i odgoj u vjeri nije pružio samo temeljne smjernice i vjerske

\footnotetext{
${ }^{7}$ Usp. A. MATE-TOTH, P. MIKLUŠČAK, Nije kao med i mlijeko, Zagreb, 2001., 21.

${ }^{8}$ Usp. isto, 17.

${ }^{9}$ S. ŠOTA, Sudbina vjeronauka u Đakovačkoj i Srijemskoj biskupiji od 1944.-1960., Zagreb, 2011., 397.

${ }^{10}$ Usp. isto, 398-413.

${ }^{11}$ Usp. isto, 415-417.
} 
pouke za sve uzraste vjernika, od djece do starih i bolesnih, te progovorio o obnovi vjerskoga života nego je i ukazao na veliku žilavost, umješnost i uspješnost Crkve da i u vrijeme otežanih okolnosti za evangelizacijsko i katehetsko djelovanje ostvari temeljno poslanje naviještanja prepoznajući prioritete, mogućnosti i poteškoće u širenju radosne vijesti, evanđelja. ${ }^{12}$ U Đakovačkoj i Srijemskoj biskupiji 1981. godine pokrenuli su se tečajevi priprave za brak i obitelj radi što kvalitetnije pripreme za bračni i obiteljski život. ${ }^{13}$ Godine 1988. organizirao se znanstveni simpoziji o braku i obitelji sa željom prepoznavanja pastoralnih prioriteta i pronalaska što kvalitetnijih modela rada. ${ }^{14}$ Nakon Drugoga vatikanskoga koncila koji je cijeloj Crkvi dao novi duh, zanos, žar na mnogim područjima, napose u evangelizacijskom smislu, 70-ih i 80-ih godina i u Crkvi u Hrvata, a time i u Đakovačkoj i Srijemskoj biskupiji, pastoral u župama postaje sveobuhvatniji, sustavniji, kvalitetniji i redovitiji. Redovitost se najviše očitovala u župnoj katehezi, posebice pripravi djece i mladih za sakramente pričesti i krizme. No unatoč mnogobrojnim nastojanjima permanentne formacije za svećenike ${ }^{15} \mathrm{i}$ časnih sestara ${ }^{16} \mathrm{u}$ mentalitetu velikoga broja vjernika katolika zadržao se komunistički stav da su vjera i crkvenost isključivo privatne, mentalitet koji je onemogućio i otežao kršćaninov angažman na crkvenoj i društvenoj razini. ${ }^{17}$ Dakle getoizacijom i marginalizacijom Crkve i njezinim tjeranjem u sakristije vjernik nakon komunizma nije samo (iz)gubio teološki, kulturni, sociološki i tradicionalni vid identiteta nego je zbog polustoljetne izolacije u velikoj mjeri postao sekulariziran, vjerski nepoučen, indiferentan, eklezijalno i pastoralno pasivan, sakramentalno udaljen i nesuživljen s Crkvom. ${ }^{18}$

${ }^{12}$ Usp. BISKUPI JUGOSLAVIJE, Radosno naviještanje Evandelja i odgoj u vjeri, Zagreb, 1983., 5-133.

${ }^{13}$ Osnivač i glavni pokretač tečajeva priprave za brak bio je dr. Pero Aračić, profesor pastoralne teologije u Đakovu. Usp. P. ARAČIĆ, Rastimo u ljubavi, 1-9, Đakovo, 1981., 1-20.

${ }^{14}$ Usp. P. ARAČIĆ (ur.), Uspjeli brak-sretna obitelj, Đakovo, 1989., 7-238.

${ }^{15}$ Usp. Održavanje Teološkog pastoralnog tjedna u Zagrebu, krajem siječnja svake građanske godine.

${ }^{16}$ Usp. Teološko-katehetsku formaciju na Teološko-katehetskom institutu u Zagrebu koji djeluje i danas kao sastavnica Katoličkoga bogoslovnoga fakulteta u Zagrebu.

${ }^{17}$ Usp. J. BALOBAN, Pastoralna teologija u Hrvatskoj, u: I. DŽINIĆ, I. RAGUŽ (ur.), Iščekivati i požurivati dolazak dana Božjega. Zbornik radova u čast prof. dr. sc. Peri Aračiću prigodom 65. obljetnice života, 15-32., ovdje 22.

${ }^{18}$ Izrečena konstatacija o vjerniku Crkve u Hrvata nakon komunizma utemeljena je na sveobuhvatnom istraživanju stanja vjerske pouke $\mathrm{u}$ Đakovačkoj i Srijemskoj biskupiji u sklopu doktorske disertacije koju je autor rada nakon obrane i objavio. Usp. S. ŠOTA, Sudbina vjeronauka u Đakovačkoj i Srijemskoj biskupiji od 1944.-1960., 417-418. 


\subsection{DRUŠTVENI I CRKVENI KONTEKST SAZIVANJA DRUGE BISKUPIJSKE SINODE ĐAKOVAČKE I SRIJEMSKE NAKON PRVIH DEMOKRATSKIH IZBORA 1990. GODINE}

Na prvim demokratskim izborima u Hrvatskoj u proljeće 1990. godine, poslije četrdeset i pet godina totalitarnoga komunističkoga režima, pobijedio je dr. Franjo Tuđman iz HDZ-a s ciljem stvaranja slobodne samostalne hrvatske države neovisne o drugim republikama tadašnje Jugoslavije. Ranije osmišljeni plan stvaranja Velike Srbije novoizabranu vlast u Hrvatskoj snažnom propagandom proglašavao je zločinačkom radi stvaranja preduvjeta ne samo za »okvir za mržnju protiv Hrvata $\ll{ }^{19}$ nego i, pod vidom ugroženosti srpske manjine u Hrvatskoj, za početak prvotno $\gg$ tihe i puzajuće $\ll^{20}$, a kasnije, u proljeće 1991. godine ${ }^{21}$, i otvorene agresije na Hrvatsku s krajnjim ciljem stvaranja Velike Srbije na crti Virovitica - Karlovac - Karlobag. Temeljno polazište velikosrpske ideje očitovalo se u činjenici da je svaka hrvatska država po sebi zločinačka (ustaška).Stoga je pod izlikom građanskoga sukoba, a ne otvorene agresije jedne suverene države na drugu, Srbija uz pomoć JNA, paravojnih formacija Srbije i velikoga dijela domaćih Srba u Hrvatskoj, izvršila agresiju na Republiku Hrvatsku. Prvi dio Domovinskoga rata obilježen je bezdušnim, iracionalnim, zločinačko-genocidnim razaranjem grada Vukovara i njegove okolice. Tijekom ljeta i jeseni 1991. godine gotovo sva mjesta i župe Đakovačke i Srijemske biskupije bile su izložene napadima, protjerivanju, ubijanju, uništenju imovine, napose crkava i župnih domova, mnogobrojnim mučenjima, silovanjima i ubijanju. Sva sela i župe u Baranji okupirana su u kolovozu 1991. godine. Ilok i okolica okupirani su tijekom listopada. Posljednje borbe do konačnoga pada u Vukovaru i Borovu naselju vodile su se do 18., odnosno 19. studenoga. U prosincu su sela oko grada Osijeka Laslovo, Ostrvo, Antunovac, Ernestinovo i Tenja također okupirali srpski osvajači i JNA koja je bila u službi ostvarenja Velike Srbije. ${ }^{22}$ Osijek,

\footnotetext{
${ }^{19}$ D. DOMAZET-LOŠO, Hrvatski Domovinski rat 1991.-1995., Zagreb, 2010., 115.

${ }^{20}$ Odnosi se na događaje iz nacionalnoga parka Plitvička jezera 31. ožujka 1991. godine i događaja 2. svibnja 1991. godine u Borovo Selu. Usp. isto, 120.

${ }^{21}$ Otvorena agresija na Hrvatsku započela je 25. lipnja 1991. godine, odmah nakon odluke Hrvatskoga sabora o samostalnosti i neovisnosti Hrvatske. Usp. isto, 162.

${ }^{22}$ Dr. Marin Srakić, nadbiskup u miru, o materijalnim štetama na sakralnim objektima na okupiranom području biskupije, iznoseći točne podatke, piše: »crkve i kapele: uništene (23), teško oštećene (24), lakše oštećene (22); župne kuće i samostani: uništene (6), teško oštećene (21), lakše oštećene (8); inventari crkava: uništeni (50), teško oštećeni (14), lakše oštećeni (4); inventari župnih kuća: uništeni (2), teško oštećeni (1), lakše oštećeni (3); vjeronaučne dvorane: uništene (10), teško oštećene (5); manje kapele: uništene (15), teško oštećene (6), manje oštećene (1); križevi: uništeni $(6) . \ll$ M. SRAKIĆ, Ratne štete i obnova crkvenih objekata na području Đakovačke i Srijemske biskupije, u: M. BREKALO (ur.), Domovinski rat i njegovi društveno-ekonomski odrazi na razvoj hrvatskog Istoka, Zagreb, 2016., 15-35., ovdje, 24.
} 
Đakovo i Vinkovci neprestano su izloženi svakodnevnim napadima. ${ }^{23}$ Takvo stanje intenziviralo se nakon 15. siječnja 1992. godine kada je velik dio europskih zemalja priznao Republiku Hrvatsku. Napadi na neokupirani dio Đakovačke ili Bosanske biskupije nastavljeni su sve do dolaska mirovnih snaga Ujedinjenih naroda u veljači i ožujku 1992. godine. ${ }^{24}$ Đakovačka i Srijemska biskupija najviše je stradala od svih biskupija u Hrvatskoj za vrijeme Domovinskoga rata. Njezin prostor od $11286 \mathrm{~km}^{2}$ rat je raskomadao na tri dijela: $\gg$ srijemski dio na području Srbije, između državne granice Hrvatske i Srbije i Zemuna, odnosno Novog Beograda, površine od 4000 $\mathrm{km}^{2}$; okupirani dio istočne Slavonije, zapadnog Srijema i Baranje, površine od 2000 $\mathrm{km}^{2}$; slobodni dio, površine od $4768 \mathrm{~km}^{2}$. Biskupija je tada imala 178 kanonski ustanovljenih župa, 214 dijecezanskih svećenika, od kojih je, osim pastoralnih svećenika, bilo 20 profesora, 17 umirovljenika, 24 prognanika, 12 na radu u inozemstvu, te 6 svećenika na studiju u inozemstvu. Ratne strahote na području Biskupije počele su krvoprolićem hrvatskih redarstvenika u Borovu Selu 2. svibnja 1991. godine i trajale su do kolovoza 1995. U razdoblju od srpnja 1991. do prosinca iste godine s područja Biskupije bilo je protjerano ili izbjeglo oko 250000 stanovnika, što je polovica vjernika katolika cijele biskupije. Oko 100000 prognanika punih se šest godina nije moglo vratiti u svoje domove, koji su bili ili srušeni ili nastanjeni Srbima pridošlim iz zapadne Slavonije. Mnogi mladi nisu se nikad vratili, iako im je država obnovila kuće i stanove. $U$ isto vrijeme na području Đakovačke biskupije nalazilo se oko 95000 izbjeglica iz Bosanske Posavine. Na području biskupije poginulo je 4 000, nestalo 15000 (1256 u Vukovaru), a ranjeno je 7000 osoba. $\ll{ }^{25} \mathrm{Na}$ području istočnoga Srijema, u kojem nije bilo ratnih sukoba, iz 28 župa protjerano je 20000 Hrvata, vjernika katolika. Manji dio protjeranih nastanio se na području Đakovačke biskupije, veći dio nastanio se u ostalim dijelovima Hrvatske ili inozemstvu. U Srijemu je ostalo oko 30000 vjernika katolika. ${ }^{26}$ Dakle tijekom rata u Hrvatskoj, a u isto vrijeme u zaleđu Hrvatske, odvijala se teška borba za goli život i opstanak Hrvata u Srijemu. Bila je to borba za ljudska i građanska prava, pravo na ime, kulturu, naciju, vjeru, politički i društveni angažman. Mnogi su katolici bili izloženi različitim torturama, velika većina prisilno je iseljena, a ostatak u određenoj mjeri

\footnotetext{
${ }^{23}$ Dr. Marin Srakić, nadbiskup u miru, o materijalnim štetama na sakralnim objektima na slobodnom području biskupije, iznoseći točne podatke, piše: »crkve i kapele: uništene (1), teško oštećene (18), lakše oštećene (31); župne kuće i samostani: uništene (2), teško oštećene (16), lakše oštećene (29); inventari crkava: teško oštećeni (7), lakše oštećeni (5); inventari župnih domova: uništeni (1), teško oštećen (1); vjeronaučne dvorane: uništene (5), teško oštećene (1), lakše oštećene 3), manje kapele: teško oštećene (7), lakše oštećene (1); križevi: teško oštećeni (6), lakše oštećeni (2) «. Isto, 25.

${ }^{24}$ Usp. D. RUNTIĆ, Domovinski rat umijeće pregovaranja, Vinkovci - Šibenik, 2007., 401-412.

${ }^{25}$ M. SRAKIĆ, Ratne štete i obnova crkvenih objekata na području Đakovačke i Srijemske biskupije, 20.

${ }^{26}$ Usp. isto, 21.
} 
i danas živi obespravljen. Dr. Milan Bičanić, govoreći o stanju u istočnom Srijemu, ističe: »Grobovi žrtava velikosrpskog zločina, tisuće protjeranih i nepoznate sudbine nestalih srijemskih Hrvata - to je bilanca rata protiv Hrvata i svega hrvatskoga na području Srijema... Velikosrpstvo ne tolerira ništa i nikog što je drugačije od njegova mitskoga sna. ${ }^{27} \mathrm{U}$ takvim okolnostima gotovo je bilo nemoguće redovito sustavno evangelizirati, a biskupija Đakovačka ili Bosanska i Srijemska, silom prilika, vrlo brzo i neočekivano promijenila je vlastito lice i naličje, ne samo s obzirom na broj vjernika raseljenih i iseljenih na sve strane svijeta, zatim razrušenih i oštećenih crkava i župnih domova, vjeronaučnih dvorana, križeva, kapelica, isto tako u velikoj mjeri uništenih gospodarstava i domova nego i zbog činjenice da su mnoge obitelji trpjele razne i mnogobrojne rane i traume na duši i tijelu.$^{28}$ Dakle uz materijalne strahote Biskupija se i prije početka mirne reintegracije 1996. godine te povratka većega dijela stanovništva vlastitim domovima našla pred izazovima nevolja fizičke, psihičke i duhovne naravi, odnosno promjene u osobnosti. Naglo se povećao broj osoba ovisnih o alkoholu, drogi i kocki, mnogi su branitelji uz posljedice ranjavanja oboljeli od posttraumatskoga stresnoga poremećaja (PTSP-a), ${ }^{29}$ dok je velik broj vjernika osjećao prijezir i mržnju prema agresoru, što se posebno očitovalo u trenutcima povratka. ${ }^{30} \mathrm{Jedan}$ od razloga jest činjenica da je dio mučitelja, silovatelja i ubojica zbog sveopće amnestije ostao u svojim selima i gradovima, a žrtve su se nerijetko s njima susretale. Nadalje velik je broj obitelji zbog člana oboljeloga od PTSP-a također patio i nerijetko obolio, napose djeca i mladi od tzv. transgeneracijskoga sindroma istraumatiziranosti. ${ }^{31}$ Kada se tomu pridodala ostavština višedesetljetne komunističke bezbožne ideologije, tada se snažno osjetila potreba sazivanja biskupijske sinode kako bi se proanaliziralo stanje i prepoznale mogućnosti, potrebe i perspektive pastoralnoga i katehetskoga djelovanja partikularne Crkve đakovačke i srijemske.

${ }^{27}$ M. BIČANIĆ, Srijem krvavo krilo Hrvatske, 8.

${ }^{28}$ Usp. V. GRUDEN, Ožiljci na duši Hrvatske, 82-104.

${ }^{29}$ Usp. R. GREGUREK, Psihički aspekti posttraumatskog stresnog poremećaja, u: R. GREGUREK, E. KALIN (ur.), Posttraumatski stresni poremećaj - hrvatska iskustva, Zagreb, 2000., 45-52.

${ }^{30}$ Autor rada više godina radio je s braniteljima, posebice braniteljima koji su oboljeli od posttraumatskoga stresnoga poremećaja. Mnogi od njih na početku grupnih ili individualnih terapija osjećali su jedan od vidova prijezira i mržnje prema agresoru - Srbima. Više o tome: S. ŠOTA, Nietzscheovsko, egzistencijalno-kršćansko te kristovsko poimanje mira i pomirenja stradalnika Domovinskog rata u Đakovačko - osječkoj nadbiskupiji, u: M. BREKALO (ur.), Domovinski rat i njegovi društveno-ekonomski odrazi na razvoj hrvatskog Istoka, 365-383.

${ }^{31}$ Usp. D. DE ZAN, Dijete i trauma, u: R. GREGUREK, E. KALIN (ur.), Posttraumatski stresni poremećaj-hrvatska iskustva, 144-146. 


\section{Kratki prikaz sinodskih događanja od sazivanja do objave dokumenta Ti si Krist-za nas i za sve ljude}

Tijekom i nakon rata, a napose nakon mirne reintegracije okupiranoga dijela 1998. godine uočavala se na razini mjesne Crkve potreba ozbiljne, realne i konstruktivne analize stanja i kritičkoga promišljanja što (u)činiti kako bi se crkveni život što kvalitetnije strukturirao, organizirao, osmislio, posebice pronašao konstruktivniji i odgovarajući način evangelizacijskoga djelovanja koji će se uhvatiti u koštac s novim izazovima društvenoga, osobito pastoralnoga i katehetskoga života Crkve. ${ }^{32}$ Prvi koji je progovorio o potrebi sazivanja Druge biskupijske sinode dakovačke i srijemske bio je umirovljeni prof. dr. Pero Aračić koji je kao rektor Teologije u Đakovu, čestitajući Božić, biskupu, profesorima, studenticama i studentima 23. prosinca 1994. godine rekao: »Naša biskupija danas je razderana poput Kristove haljine. Srijemska biskupija živi poput onih prvih vremena progona kršćana... Preostali dio preplavljen je izbjeglicama i prognanima ... Danas, više nego li jučer, potrebno je od najmanjih zajednica do biskupijskih struktura, omogućiti ono što znači biti Crkvom. ŽPV, ŽEV, BPV, PV, savjetodavna tijela, sve su to strukture po kojima svi odazvanici Isusovi mogu izraziti i ostvarivati svoje sljedbeništvo...Gospodine biskupe, možda bi u ovo vrijeme bilo važnije učiniti inventuru u biskupiji, nego li u neka manje problematična vremena. Možda bi bilo potrebno sazvati biskupijsku sinodu upravo sada i pokrpati i povezati ovu rastrganu haljinu. Nije li potrebno jasnije se opredijeliti u pastoralnim usmjerenjima? Utjelovljenje kao događaj ali i trajno zbivanje temeljna je odrednica crkvenog djelovanja. Zahtijeva od nas da ulazimo u svu stvarnost i nju zahvatimo. Ne dopušta nam neka čekanja i propuštanja. ${ }^{33} \mathrm{Tri}$ godine kasnije u svom nastupnom govoru nakon imenovanja biskupom đakovačke i srijemske biskupije, 5. svibnja 1997. godine, dr. Marin Srakić jednim je od pastoralnih prioriteta imenovao sazivanje Druge biskupijske sinode dakovačke i srijemske. ${ }^{34}$

${ }^{32}$ Dr. Drago Iličić napisao je i obranio 2006. godine na Katoličkom bogoslovnom fakultetu u Zagrebu doktorski rad pod nazivom Pastoralni aspekti Druge biskupijske sinode đakovačke i srijemske, i u njemu je na najsustavniji način opisan predsinodski i sinodski hod, autor članka zbog toga se u radu sustavnije ne zadržava na predsinodskim i sinodskim vremenom. Autor iznosi samo osnovne činjenice radi lakšega i kvalitetnijega praćenja analize trećega dijela rada, odnosno kritičkoga osvrta pastoralnih nastojanja nakon objave sinodskoga dokumenta Ti si Krist - za nas i za sve ljude. Izjave i odluke Druge sinode Đakovačke i Srijemske biskupije. Dr. Iličić napisani je i obranjeni doktorski rad objavio dvije godine kasnije. Usp. D. ILIČIĆ, Pastoralni aspekti Druge biskupijske sinode đakovačke i srijemske, Đakovo, 2008., 436.

${ }^{33}$ Usp. Čestitka za Božić, Arhiv Katoličkog bogoslovnog fakulteta u Đakovu, od 23. prosinca 1994., br. 214/ 1994.

${ }^{34}$ Usp. D. ILIČIĆ, Pastoralni aspekti Druge biskupijske sinode dakovačke i srijemske, 57. O sazivanju Druge biskupijske sinode đakovačke i srijemske govorio je i najavljivao je i ranije dr. Marin Srakić. Kao biskup koadjutor tri puta je najavio sazivanje Sinode na Prezbiterskom vijeću 13. travnja 1996. go- 
Uskoro je Sinoda započela sa svojim pripremnim radnjama: stvaranjem Pravilnika biskupijske sinode, Nacrta rada, osnivanjem sinodskoga Pripremnoga povjerenstva, strukturiranjem povjerenstava, odbora, izabiranjem molitve, mota, himna te na kraju izdavanjem okružnice kojom je biskup Marin izvijestio o sadržaju priprave. ${ }^{35}$ Dekretom sazivanja ${ }^{36} \mathrm{i}$ imenovanjem dr. Đure Hranića tajnikom Sinoda je službeno sazvana tijekom euharistijskoga slavlja30. svibnja 1998. godine. ${ }^{37}$ Temeljni cilj Sinode bio je mjesnu Crkvu okupiti, bolje upoznati crkvenu i vjerničku stvarnost i realnost, posebice na područjima evangelizacije, liturgije, kršćanskoga poziva i služenja te ustroja biskupijske zajednice. ${ }^{38} \mathrm{Na}$ taj način sinodske odluke trebale bi pridonijeti rješenju teškoća i nužnoj prementalizaciji na evangelizacijskom, pastoralnom i katehetskom području, posebice utjecati i mijenjati piramidalno strukturirano pastoralno djelovanje, nerijetko uvjetovano komunističkim naslijeđem koje nije omogućavalo osnaživanje i jačanje koncilske obnove mjesne Crkve na temelju saborske ekleziologije i postsaborskih crkvenih promišljanja. Doprinos je Sinoda trebala dati u stvaranju novih oblika i načina pastoralnoga djelovanja. Koncilskim shvaćanjem Crkve kao Božjega naroda u kojem su svi vjernici na postavkama eklezijalnosti, sinodalnosti i supsidijarnosti suodgovorni u izgradnji, životu i poslanju Crkve. Druga biskupijska sinoda đakovačke i srijemske biskupije tijekom pripravnoga, a kasnije i sinodskoga vremena snažno je isticala koncilsku ekleziologiju i pastoralno djelovanje kao temeljnu postavku. ${ }^{39}$ Kao što je liturgija srce župe i vjerničkoga života, koja kroz dimenzije naviještanja i služenja izgrađuje zajednicu, ${ }^{40}$ tako je i pastoralno djelovanje sinodalnoga karaktera Đakovačke i Srijemske biskupije zamišljeno da planove, programe, inicijative i sadržaje pastoralnoga djelovanja, koje je osmislio biskupski središnji koordinacijski ured, pretače na regionalnu, dekanatsku, napose župnu razinu. ${ }^{41}$

dine. O pripremnom razdoblju, početnim koracima, preliminarnim sastancima, susretima Odbora i voditelja pojedinih odbora usp. isto.

${ }^{35}$ Usp. isto, 57-63.

${ }^{36}$ Usp. M. SRAKIĆ, Dekret sazivanja Druge biskupijske sinode đakovačke i srijemske, u: Vjesnik Đakovačko-osječke nadbiskupije i Srijemske biskupije (=VĐSB) 126(1998.)6, 410.

${ }^{37}$ Usp. D. ILIČIĆ, Pastoralni aspekti Druge biskupijske sinode đakovačke i srijemske, 63.

${ }^{38}$ Usp. Ti si Krist - za nas i za sve ljude. Izjave i odluke Druge biskupijske sinode dakovačke i srijemske, Đakovo, 2008.

${ }^{39}$ DRUGI VATIKANSKI KONCIL, Dogmatska konstitucija o Crkvi »Lumen gentium «, u: ISTI, Dokumenti, Zagreb, ${ }^{7} 2008$., br. 30-34.

${ }^{40}$ Usp. DRUGI VATIKANSKI KONCIL, Konstitucija o svetoj liturgiji »Sacrosanctum concilium «, u: ISTI, Dokumenti, Zagreb, ${ }^{7} 2008$., br. 7-10.

${ }^{41}$ Usp. Ti si Krist - za nas i za sve ljude, br. 662. 
Tablica 1. Predsinodalni pristup i način pastoralnoga djelovanja u Đakovačkoj i Srijemskoj biskupiji

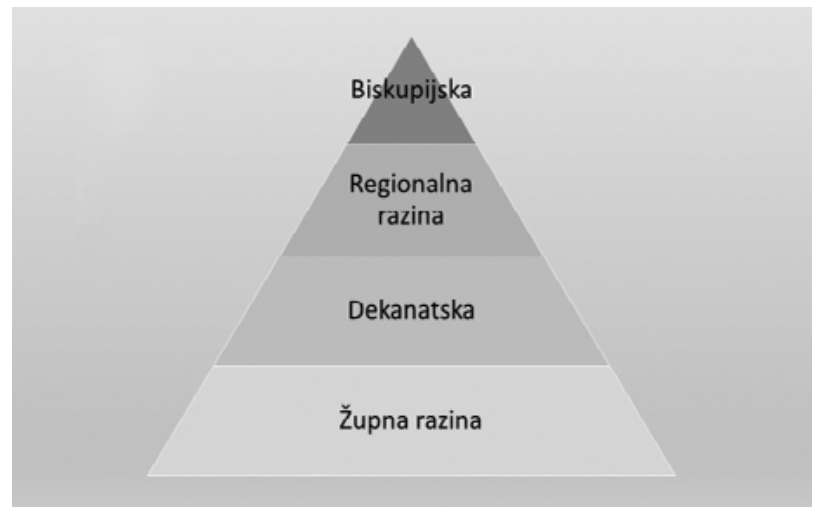

Tablica 2. Koncilska ekleziologija i poimanje župe - paradigma sinodalnoga pastoralnoga djelovanja

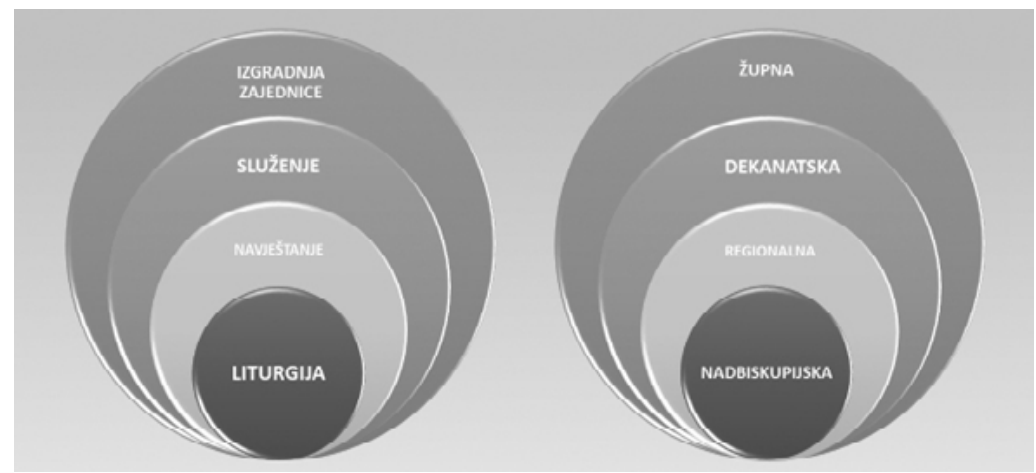

Nakon nastojanja da se upozna stvarno stanje evangelizacijske, pastoralne i katehetske dimenzije vjerničkoga života na župnoj, međužupnoj i biskupijskoj razini, na sinodskim zasjedanjima raspravljalo se kako poboljšati ili u nekim vidovima promijeniti pastoralnu praksu te donijeti zaključke koji bi omogućili biskupu izradu završnoga dokumenta koji će precizirati, odrediti, napose usmjeriti život i djelovanje biskupije. Tijekom sinodskoga hoda održana su četiri zasjedanja: o evangelizaciji, liturgiji, kršćanskom pozivu i služenju te ustroju biskupijske zajednice: »prvo: 15. - 18. listopada 2000., drugo: 15. - 17. ožujka 2001., treće: 25. - 27. listopada 2001., četvrto: 2 . -5 . listopada $2002 .{ }^{42}$ Jedna od velikih poteškoća tijekom pripravnoga

${ }^{42}$ M. SRAKIĆ, Dekret proglašenja Izjava i odluka Druge biskupijske sinode đakovačke i srijemske, u: Ti si Krist - za nas i za sve ljude. Izjave i odluke Druge biskupijske sinode đakovačke i srijemske, 5. 
razdoblja, posebice tijekom sinodskoga hoda i zasjedanja, jest činjenica da se jedan dio svećenika, odnosno župnika, uopće nije uključio u sinodska događanja ili je to učinjeno na vrlo skromnoj razini. Tako na području Đakovačke biskupije u 18 od 149 župa nije održan ni jedan susret. Kada se tomu pribroji još 19 župa Đakovačke biskupije u kojima je za vrijeme cjelokupnoga sinodskoga razdoblja održano manje od deset susreta, tada možemo ustvrditi da u Đakovačkoj biskupiji, ne računajući Srijemsku biskupiju, sinodski hod nije nikako ili je vrlo slabo zaživio u $24,8 \%$ župa. ${ }^{43}$

\section{Tablica $3 .^{44}$}

\begin{tabular}{|c|c|c|c|c|c|c|c|}
\hline \multirow{2}{*}{\multicolumn{2}{|c|}{ BROJ ŽUPA }} & \multicolumn{3}{|c|}{$\begin{array}{l}\text { OSTVARENI RAZGOVORI U } 13 \\
\text { DEKANATA DAKOVAČKE BISKUPIJE }\end{array}$} & \multicolumn{3}{|c|}{$\begin{array}{l}\text { ŽUPE U KOJIMA NIJE OSTVAREN } \\
\text { NI JEDAN RAZGOVOR }\end{array}$} \\
\hline & & \multicolumn{3}{|r|}{4772} & & & 15 \\
\hline \multicolumn{4}{|c|}{$\begin{array}{l}\text { ŽUPE U KOJIMA JE OSTVARENO NAJVIŠE } \\
\text { RAZGOVORA (5) }\end{array}$} & \multicolumn{4}{|c|}{$\begin{array}{l}\text { ŽUPE U KOJIMA JE OSTVARENO NAJMANJE } \\
\text { RAZGOVORA (5) }\end{array}$} \\
\hline GRAD & & SELO & & GRAD & & SELO & \\
\hline Županja 1 & (387) & Podravski Podgajci & (129) & Vinkovci 5 & (1) & Odvorci, Vrbica & (1) \\
\hline Donji Miholjac & (134) & Bošnjaci & (113) & Ilok & (6) & Rajevo Selo & (2) \\
\hline Županja 2 & (113) & Duboševica-Topolje & $(82)$ & Vinkovci 6 & (7) & $\begin{array}{l}\text { Jarmina, Sarvaš } \\
\text { (4) }\end{array}$ & Eenja \\
\hline Osijek 6 & (99) & Donji Andrijevci & $(61)$ & Slavonski Brod 3 & $(27)$ & Radikovci & (7) \\
\hline Osijek 3 & (86) & Bapska, Garčin & $(57)$ & Beli Manastir & $(40)$ & $\begin{array}{l}\text { Bar.Petr. Selo- } \\
\text { (8) }\end{array}$ & rjanci \\
\hline
\end{tabular}

Od posljednjega zasjedanja koje je bilo od 2. do 5. listopada 2002. godine do 6 . srpnja 2008. godine kada je mons. dr. Marin Srakić, nadbiskup i metropolit Đako-

\footnotetext{
${ }^{43}$ Autor rada prikazujući u tablici 3. pet gradskih i pet seoskih župa u kojima se tijekom Sinode najviše ili najmanje održalo susreta ne izjednačava i ne promatra sve župe jednako. Kao koordinator Pastoralnoga centra Đakovačko-osječke nadbiskupije smatra kako u velikoj mjeri poznaje fizionomiju župa Nadbiskupije, posebice relativno mu je poznat kontekst, specifičnost i narav svake župe. Autor rada želi ukazati na činjenicu kako je sinodsko događanje i sinod gotovo u potpunosti ovisio o angažiranosti župnika predvoditelja, vođe i pastira župne zajednice, te kako je zbog toga izostanak sinodskoga hoda u 24,8 \% župa Đakovačke biskupije imalo velikih posljedica u implementaciji, konkretizaciji, napose ostvarenju i realizaciji sinodskih zaključaka, ne samo u tim župama nego i u jednom dijelu ostalih župa, napose ondje gdje se dogodila promjena župnika, župnika koji nije bio zainteresiran za sinodski hod i događanje.
}

${ }^{44}$ Usp. D. ILIČIĆ, Pastoralni aspekti Druge biskupijske sinode dakovačke i srijemske, 400-404. 
vačko-osječke nadbiskupije, odobrio, proglasio, odredio i objavio Knjigu sinode ${ }^{45}$ u župama u kojima je sinodski hod snažnije zaživio možemo govoriti o vremenu evangelizacijske i pastoralne uzbibanosti, iščekivanja, napose priprave u strukturalnom i infrastrukturalnom smislu riječi. Najsnažniji zamah sinodskom događanju pružio je sveti Ivan Pavao II. tijekom svojega trećega pastirskoga pohoda Hrvatskoj rekavši tijekom euharistijskoga slavlja u Osijeku 7. lipnja 2003. godine: »Pođite $\mathrm{u}$ svoje vjerničke zajednice, u svoje domove i na svoja radna mjesta te, kao vjerni učenici Gospodinovi, u duhu Evanđelja u svojoj životnoj svakodnevici ostvarujte sinodske odluke. $\ll{ }^{46}$ Narav, svrhu i cilj sinodskoga događanja Druge biskupijske sinode đakovačke i srijemske najbolje je opisao njezin idejni začetnik i pokretač mons. dr. Marin Srakić riječima: »Neka ova knjiga bude istinsko uporište i pastoralno pravilo života i poslanja Crkve đakovačko-osječke.« Mons. Srakić poziva sve svećenike, redovnike i redovnice i sve Kristove vjernike da u duhu istinskoga zajedništva prihvate odredbe donesene $u$ Knjizi sinode te se marno njome služe $u$ ispunjavanju svojega poslanja - življenja i naviještanja evanđelja, radosne vijesti spasenja u Isusu Kristu. Mons. Srakić nastavlja: »Neka nas u tome prati Blažena Djevica Marija, Zvijezda nove evangelizacije... $\ll{ }^{47}$ Nova evangelizacija ključna je riječ predsinodskoga, sinodskoga i postsinodskoga vremena Druge biskupijske sinode dakovačke $i$ srijemske. Prema Thomasu Södingu, članu Međunarodne teološke komisije te čla$\mathrm{nu}$ - savjetniku Papinskoga vijeća za promicanje nove evangelizacije, evangelizacija je »teško ime za važnu stvar. Ime je teško; zato što je evangelizacija uvijek nova ili nije istinsko naviještanje (...), a novost evangeliziranja potječe iz životnosti Božje riječi, a ne iz novih opisa situacije i strateških papira. Evanđelje u svojoj snazi uvijek ostaje staro, naime jedna dobra vijest, kojoj su, dok prolazi vremenima, stalno potrebne nove govornice i govornici, stalno novi putovi i metode, i ona ih i nalazi. A stvar je važna zato što staro razlikovanje između misije ad gentes i kateheze (kao mistagogije) više ne pali, kada se među kršćanima širi religiozni analfabetizam. Nova evangelizacija hoće ovdje započeti. Ona je borba velikoga stila protiv analfabeta u stvarima vjere (...) ona je čvrsta odluka da se danas vjera unese u razgovor u novim oblicima i na novim forumima, s novim protagonistima i u novim koalicijama $\ll_{.}{ }^{48}$ Sinodski dokument Ti si Krist - za nas i za sve ljude djeluje »svježe i iskreno, moderno i napredno, emocionalni jezik važi kao autentičan, i proročki ${ }^{49}{ }^{9} \mathrm{Knjiga}$ sinode i sinodski zaključci jesu dakle ne samo partikularno pravo mjesne Crkve

\footnotetext{
${ }^{45}$ Usp. Dekret proglašenja Izjava i odluka Druge biskupijske sinode đakovačke i srijemske, 6-7.

${ }^{46}$ Isto, 6.

${ }^{47}$ Isto, 6-7.

${ }^{48}$ T. SÖDING, Radost Evanđelja - Papinsko pismo kao signal za zamah Crkve, u: Communio 40(2014.), 118-129., ovdje 119-120.

${ }^{49}$ Isto, 119.
} 


\section{Tablica 4.}

\begin{tabular}{|c|c|c|c|c|}
\hline \multicolumn{5}{|c|}{ NADBISKUPIJSKI PASTORALNI CENTAR } \\
\hline \multicolumn{2}{|c|}{$\begin{array}{l}\text { KATEHETSKI URED } \\
\text { Z-2+1/2; }\end{array}$} & \multicolumn{3}{|c|}{$\begin{array}{l}\text { Središnji koordinacijski odbor } \\
\qquad \mathrm{Z}-1 ; \mathrm{H}-1\end{array}$} \\
\hline \multicolumn{2}{|c|}{$\begin{array}{l}\text { TISKOVNI URED } \\
\text { Z-2; H }-1\end{array}$} & \multicolumn{3}{|c|}{$\begin{array}{l}\text { Područni ured u Nadbiskupskom vikarijatu u Osijeku } \\
\qquad \mathrm{Z}-1 / 2 ; \mathrm{H}-1\end{array}$} \\
\hline \multicolumn{2}{|c|}{$\begin{array}{l}\text { MEDIJSKI ARHIV I STATISTIČKI URED } \\
\text { Z - 0; } \mathrm{H}-0\end{array}$} & \multicolumn{3}{|c|}{ 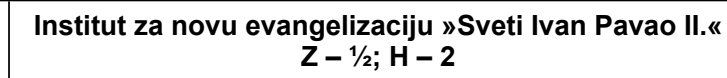 } \\
\hline 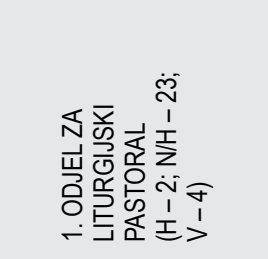 & 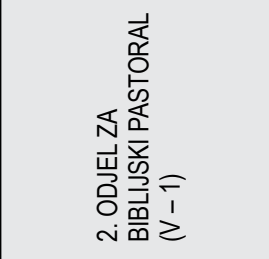 & 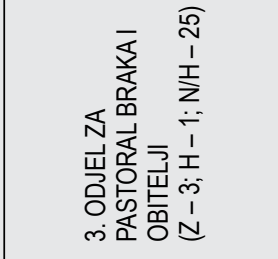 & 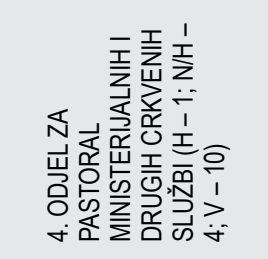 & 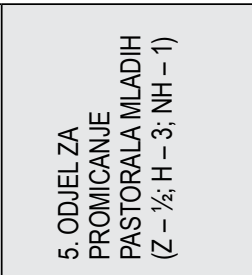 \\
\hline $\begin{array}{l}\text { Ured za liturgijski } \\
\text { pastoral i promicanje } \\
\text { liturgijskih službi V-1 }\end{array}$ & \multirow[t]{2}{*}{$\begin{array}{l}\text { Ured za biblijski pastoral } \\
\text { V-1 }\end{array}$} & $\begin{array}{l}\text { Ured za pastoral braka } \\
\text { i obitelji } \\
\mathrm{N} / \mathrm{H}-4\end{array}$ & $\begin{array}{l}\text { Djelo za trajnu } \\
\text { svećeničku izgradnju } \\
\mathrm{N} / \mathrm{H}-1\end{array}$ & $\begin{array}{l}\text { Ured za pastoral } \\
\text { mladih } \\
\mathrm{Z}-1 / 2 ; \mathrm{H}-1\end{array}$ \\
\hline $\begin{array}{l}\text { Župne liturgijske skupine } \\
\mathrm{N} / \mathrm{H}-1\end{array}$ & & $\begin{array}{l}\text { Suradnja s Vijećem HBK } \\
\text { za obitelj } \\
\text { N/H - 1 }\end{array}$ & $\begin{array}{l}\text { Povjerenstvo za TPS (pri } \\
\text { KBF-u) } \\
\text { V }-1\end{array}$ & $\begin{array}{l}\text { Ured za pastoral } \\
\text { studenata Osijek } \\
\mathrm{H}-1\end{array}$ \\
\hline $\begin{array}{l}\text { Liturgijski »Direktorij» } \\
\text { V }-1\end{array}$ & \multirow[t]{5}{*}{$\begin{array}{l}\text { Povjerenstvo za biblijski } \\
\text { pastoral }\end{array}$} & $\begin{array}{l}\text { Tečajevi priprave za brak } \\
\mathrm{N} / \mathrm{H}-15\end{array}$ & \multirow{4}{*}{$\begin{array}{l}\text { Ured za ustanove } \\
\text { posvećenog života } \\
\text { V-6 } \\
\text { Osječka regija } \\
\text { Vinkovačka regija } \\
\text { Slavonskobrodska regija } \\
\text { Vukovarska regija } \\
\text { Sestre sv. Križa u } \\
\text { Đakovu } \\
\text { Donjomiholjačka regija }\end{array}$} & \multirow{3}{*}{$\begin{array}{l}\text { Ured za pastoral } \\
\text { studenata Slavonski } \\
\text { Brod } \\
\mathrm{H}-1\end{array}$} \\
\hline $\begin{array}{l}\text { Ured za crkvenu glazbu } \\
\mathrm{H}-2\end{array}$ & & \multirow{3}{*}{$\begin{array}{l}\text { Zajednice bračnih } \\
\text { susreta Đakovačko - } \\
\text { osječke nadbiskupije } \\
\mathrm{N} / \mathrm{H}-5\end{array}$} & & \\
\hline \multirow[t]{2}{*}{$\begin{array}{l}\text { Ured za crkvenu glazbu } \\
\mathrm{H}-2\end{array}$} & & & & \\
\hline & & & & \multirow{4}{*}{$\begin{array}{l}\text { Katolička } \\
\text { malonogometna liga } \\
\mathrm{N} / \mathrm{H}-1\end{array}$} \\
\hline $\begin{array}{l}\text { Ured za gradnje i obnove } \\
\text { crkvenih objekata } \mathrm{V}-2\end{array}$ & & $\begin{array}{l}\text { Bračno i obiteljsko } \\
\text { savjetovalište Osijek } \mathrm{Z} \text { - } \\
1 ; \mathrm{H}-1\end{array}$ & $\begin{array}{l}\text { Djelo za promicanje } \\
\text { duhovnosti } \\
\text { vjeroučiteljske i } \\
\text { katehetske službe (u } \\
\text { suradnji s KU) V - } 3\end{array}$ & \\
\hline $\begin{array}{l}\text { Povjerenstvo za gradnje } \\
\text { i obnove } \\
\mathrm{N} / \mathrm{H}-21\end{array}$ & \multirow[t]{2}{*}{ Župne biblijske skupine } & $\begin{array}{l}\text { Bračno i obiteljsko } \\
\text { savjetovalište Slavonski } \\
\text { Brod Z - } 1\end{array}$ & \multirow[t]{2}{*}{$\begin{array}{l}\text { Ured za pastoral } \\
\text { ministranata } \\
\mathrm{H}-1 ; \mathrm{N} / \mathrm{H}-3\end{array}$} & \\
\hline $\begin{array}{l}\text { Restauratorski odjel } \\
\mathrm{N} / \mathrm{H}-1\end{array}$ & & $\begin{array}{l}\text { Savjetovalište za žrtve } \\
\text { obiteljskog nasilja, } \\
\text { Slavonski Brod Z - } 1\end{array}$ & & \\
\hline
\end{tabular}




\begin{tabular}{|c|c|c|c|c|c|}
\hline \multicolumn{3}{|c|}{$\begin{array}{c}\text { ŠKOLA ZA ŽUPNE SURADNIKE } \\
\text { N/H }-1 ; \mathrm{H}-1 ; \mathrm{V}-1 ; \mathrm{H}-1\end{array}$} & & & \\
\hline \multicolumn{3}{|c|}{$\begin{array}{c}\text { CARITAS } \\
\mathrm{Z}-26 ; \mathrm{H}-1\end{array}$} & & & \\
\hline \multicolumn{3}{|c|}{$\begin{array}{l}\text { VJESNIK } \\
\text { H-1; }\end{array}$} & & & \\
\hline 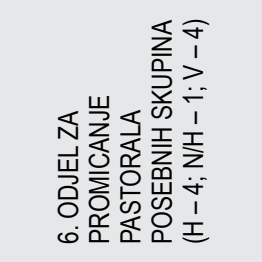 & 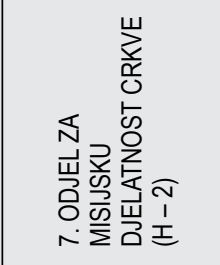 & 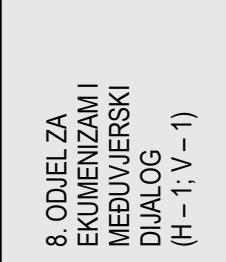 & 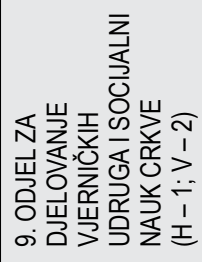 & 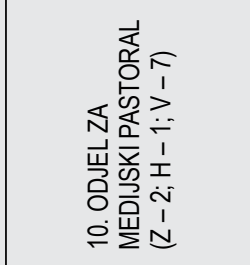 & 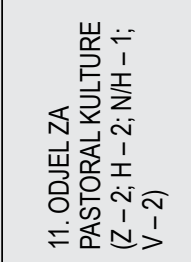 \\
\hline $\begin{array}{l}\text { Pastoral članova župnih } \\
\text { vijeća } \vee-1\end{array}$ & \multirow{2}{*}{$\begin{array}{l}\text { Ured za promicanje } \\
\text { župnih misijskih } \\
\text { skupina } \\
\mathrm{H}-1 \text {; }\end{array}$} & \multirow{11}{*}{$\begin{array}{l}\text { Ured za promicanje } \\
\text { ekumenizma } \\
\text { a) Ekumenska } \\
\text { koordinacija osječke } \\
\text { regije } \mathrm{H}-1 \\
\text { b) Animator } \\
\text { ekumenske suradnje } \\
\text { slavonsko-brodske } \\
\text { regije } \\
\text { V-1 }\end{array}$} & \multirow{3}{*}{$\begin{array}{l}\text { Ured za } \\
\text { promicanje } \\
\text { socijalnog nauka } \\
\text { Crkve i društvena } \\
\text { pitanja } \\
\mathrm{H}-1\end{array}$} & \multirow{3}{*}{$\begin{array}{l}\text { Ured za odnose s } \\
\text { javnošću - Tiskovni } \\
\text { ured } \\
\text { a) Podružnica Đakovo } \\
\text { b) Podružnica Osijek } \\
\text { V-2 }\end{array}$} & \multirow{3}{*}{$\begin{array}{l}\text { Muzej J. J. } \\
\text { Strossmayera } \\
Z-2 ; \\
H-1\end{array}$} \\
\hline $\begin{array}{l}\text { Pastoral intelektualaca } \\
\text { V }-1\end{array}$ & & & & & \\
\hline $\begin{array}{l}\text { Ured za pastoral osoba } \\
\text { s invaliditetom i njihovih } \\
\text { obitelji } \mathrm{H}-1\end{array}$ & \multirow[t]{9}{*}{$\begin{array}{l}\text { Nadbiskupijsko } \\
\text { misijsko djelo } \\
\mathrm{H}-1 .\end{array}$} & & & & \\
\hline $\begin{array}{l}\text { Pastoral bolesnika } \\
\mathrm{Z}-21 / 2 ; \mathrm{H}-2\end{array}$ & & & \multirow{8}{*}{$\begin{array}{l}\text { Ured za vjernička } \\
\text { društva } \\
\text { a) Koordinacija za } \\
\text { osječku regiju } \\
\text { V -1 } \\
\text { b) Koordinacija za } \\
\text { slavonskobrodsku } \\
\text { regiju } \\
\text { V }-1\end{array}$} & \multirow{4}{*}{$\begin{array}{l}\text { Vjesnik Đakovačko- } \\
\text { osječke nadbiskupije i } \\
\text { Srijemske biskupije } \\
\mathrm{H}-1\end{array}$} & \multirow{4}{*}{$\begin{array}{l}\text { Restauratorski } \\
\text { ured } \\
\mathrm{N} / \mathrm{H}-1\end{array}$} \\
\hline Pastoral liječnika V - 1 & & & & & \\
\hline Pastoral Roma H - 1 & & & & & \\
\hline $\begin{array}{l}\text { Pastoral zatvorenika } \\
\mathrm{H}-1\end{array}$ & & & & & \\
\hline Pastoral ovisnosti H -1 & & & & \multirow{2}{*}{$\begin{array}{l}\text { Suradnja sa župnim } \\
\text { dopisnicima i s } \\
\text { medijima } \\
V-3\end{array}$} & \multirow{4}{*}{$\begin{array}{l}\text { Ured za pastoral } \\
\text { tradicijske kulture } \\
\mathrm{H}-1 \text {; } \\
\mathrm{V}-2 .\end{array}$} \\
\hline $\begin{array}{l}\text { Pastoral vatrogasaca } \\
\text { V }-1\end{array}$ & & & & & \\
\hline \multirow[t]{2}{*}{$\begin{array}{l}\text { Pastoral vjernika } \\
\text { Slovaka } \\
\mathrm{N} / \mathrm{H}-1\end{array}$} & & & & $\begin{array}{l}\text { Nadbiskupijska } \\
\text { mrežna stranica } \\
Z-2\end{array}$ & \\
\hline & & & & $\begin{array}{l}\text { Medijski arhiv } \\
\text { V-2 }\end{array}$ & \\
\hline
\end{tabular}


đakovačko-osječke ${ }^{50} \mathrm{u}$ pravnom smislu nego i magna carta evangelizacijskoga, pastoralnoga i katehetskoga djelovanja za cijelu Nadbiskupiju. Ona jest i mora biti i postati istinsko uporište i pastoralno pravilo života i poslanja Crkve đakovačkoosječke, posebice poticaj i jasni evangelizacijski putokaz. ${ }^{51}$

\section{Kritički osvrt pastoralnih nastojanja nakon proglašenja Knjige sinode}

Nakon završetka sinodskih zasjedanja, posebice nakon objave Knjige sinode, započelo se stvaranje strukture i infrastrukture pastoralnoga djelovanja. Pojedini uredi, npr. katehetski ured i Caritas postojali su i prije sazivanja Druge biskupijske sinode dakovačke i srijemske. Odjeli, uredi, povjerenstva i odbori postupno su osnivani. ${ }^{52}$

Analizira trenutnoga stanja cjelokupnoga pastoralnoga djelovanja u Đakovačkoosječkoj nadbiskupiji, uključujući i Caritas, pokazuje kako je većina osoba koje vode urede, povjerenstva ili pojedina pastoralna područja u sklopu ili u suradnji sa središnjim koordinacijskim uredom Pastoralnoga centra Đakovačko-osječke nadbiskupije uglavnom honorarno plaćena, što znači da je to honoriranima, povremeno honoriranima i volonterima druga, treća ili četvrta služba. Spomenuta realnost po svojoj naravi ne mora biti loša, ali ukazuje na potrebu veće profesionalizacije i stručnosti pojedinih voditelja ureda, povjerenika, posebice voditelja ureda i povjerenika koji određeno pastoralno područje vode iz osobnog afiniteta. Naime, ako se izuzme Caritas u kojem je zaposleno 26 osoba, uočavamo da u ostalim područjima pastoralnoga djelovanja na području Đakovačko-osječke nadbiskupije nije zaposleno, odnosno profesionalizirano i stručno osposobljeno, ni petnaest osoba. ${ }^{53} \mathrm{Mi}$ sionarska preobrazba Crkve, prema Thomasu Södingu, ne bi smjela biti zamišljena

\footnotetext{
${ }^{50}$ Odlukom pape Benedikta XVI. 18. lipnja 2008. godine Đakovačka i Srijemska biskupija crkveno su ustrojene kao dvije samostalne biskupije. Srijemska biskupija ponovno je dobila vlastitoga biskupa, a Đakovačka biskupija uzdignuta je na rang nadbiskupije i dobila je ime Đakovačko-osječka nadbiskupija.

${ }^{51}$ Usp. Dekret proglašenja Izjava i odluka Druge biskupijske sinode đakovačke i srijemske, 6.

${ }^{52}$ Postojeća shema odjela, ureda, povjerenstava u Pastoralnom odsjeku Nadbiskupskoga ordinarijata. Usp. NADBISKUPSKI ORDINARIJAT ĐAKOVO, Kalendar susreta, Đakovo, 2017., 141.

${ }^{53}$ Osim Caritasa gdje je zaposleno 26 osoba, u središnjem koordinacijskom uredu u Đakovu zaposlena je jedna osoba; u Podružnici pastoralnoga centra u Osijeku - Vikarijatu i Institutu »sv. Ivan Pavao II.« zaposlene su dvije osobe na pola radnoga vremena; $\mathrm{u}$ katehetskom uredu na puno radno vrijeme zaposlene su dvije osobe i jedna na pola radnoga vremena; u tiskovnom uredu dvije, u bračno-obiteljskim savjetovalištima u Osijeku i Slavonskom Brodu zaposlene su tri osobe, u muzeju J. J. Strossmayera dvije. Redoviti mjesečni honorar za vođenje ureda ili povjerenstva prima 25 osoba, povremeno honorirano je 55 osoba, a 31 osoba volontira. U tablici br. 4. zaposlene označava slovo $\mathrm{Z}$, redovito honorirane $\mathrm{H}$, povremeno honorirane $\mathrm{N} / \mathrm{H}$, a volontere $\mathrm{V}$.
} 
kao zrakoprazni prostor; ona mora u sebi sadržavati nove kontekste, posebice prisutna lokalno diferencirana strateška rješenja pastoralnih planova kojima se upravlja iz središta te se pretaču u župnu zajednicu. Isti duh, način, modele i pastoralni pristup podrazumijevaju i sinodski zaključci. ${ }^{54}$

\section{Tablica 5. Prikaz željenoga pastoralnoga djelovanja} Druge biskupijske sinode đakovačke i srijemske ${ }^{55}$

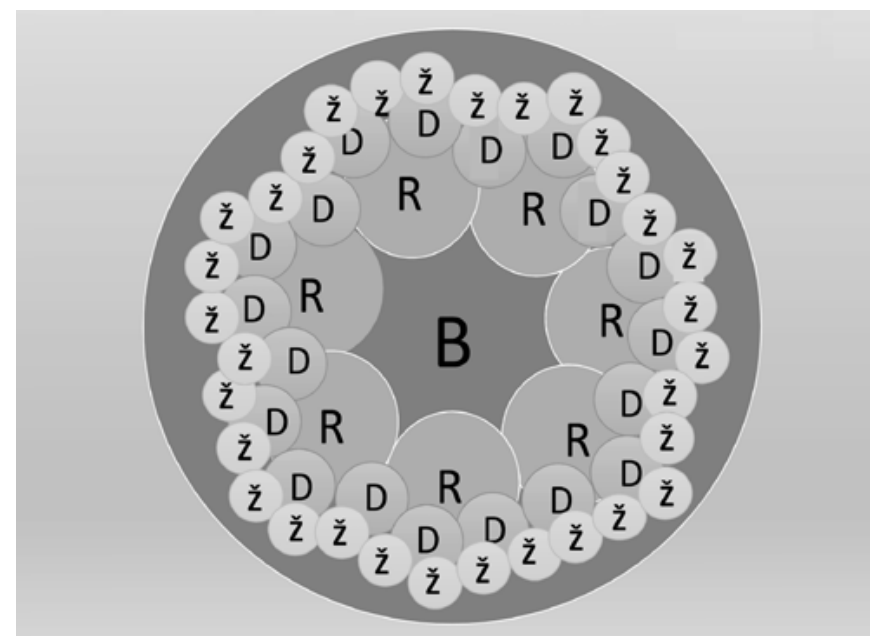

${ }^{54}$ Usp. T. SÖDING, Radost Evanđelja - Papinsko pismo kao signal za zamah Crkve, 120-121.

${ }^{55} \mathrm{U}$ tablici 5. slovo B označava (nad)biskupijsku razinu pastoralnoga djelovanja; $\mathrm{R}$ označava regionalnu razinu pastoralnoga djelovanja; D označava dekanatsku razinu pastoralnoga djelovanja; $\check{Z}$ označava župnu razinu. Tablica 5. ima za cilj prikazati strukturirano pastoralno djelovanje od nadbiskupijske do župne razine. Na nadbiskupijskoj razini Knjiga sinode ističe kako temeljni, osnovni, inicijalni pastoralni planovi, programi te inicijative trebaju dolaziti od nadbiskupijske razine, postupno se pretakati do župne razine jer je župna razina, župna zajednica, župa: »temeljna ustanova u organizacijskoj strukturi Crkve te temeljna stanica zajedništva kršćanskog života, tj. noseća ustrojbena jedinica i jezgra pastoralnoga djelovanja Crkve. Ekleziologija zajedništva, osobito zbog prilika suvremenoga načina života, a na temelju koncilskoga shvaćanja Crkve, zahtijeva i određene obnoviteljske korake u oblikovanju i organiziranju života unutar pojedinih župnih zajednica. Korjenita obnova kršćanskog tkiva samih crkvenih zajednica nezaobilazno se mora odnositi i na župne strukture. Čini se tako da je perspektiva obnovljenoga lika župe upravo njezino oblikovanje kao zajednice manjih zajednica Druga biskupijska sinoda đakovačka i srijemska prepoznaje vrijednost i važnost župe kao temeljne strukture pastoralnog djelovanja u biskupijskoj zajednici te pastoral župne zajednice želi uskladiti sa zahtjevima novijih crkvenih dokumenata i zahtjevima suvremenog pastoralnog rada. « Ti si Krist - za nas i za sve ljude, br. 554. Zbog navedenoga koncilsko-eklezijalnoga poimanja župe u tablici br. 5. najviše je prikazano slovo Ž koje označava župnu zajednicu mnogobrojnih zajednica. 
Diacovensia 27(2019.)1 •

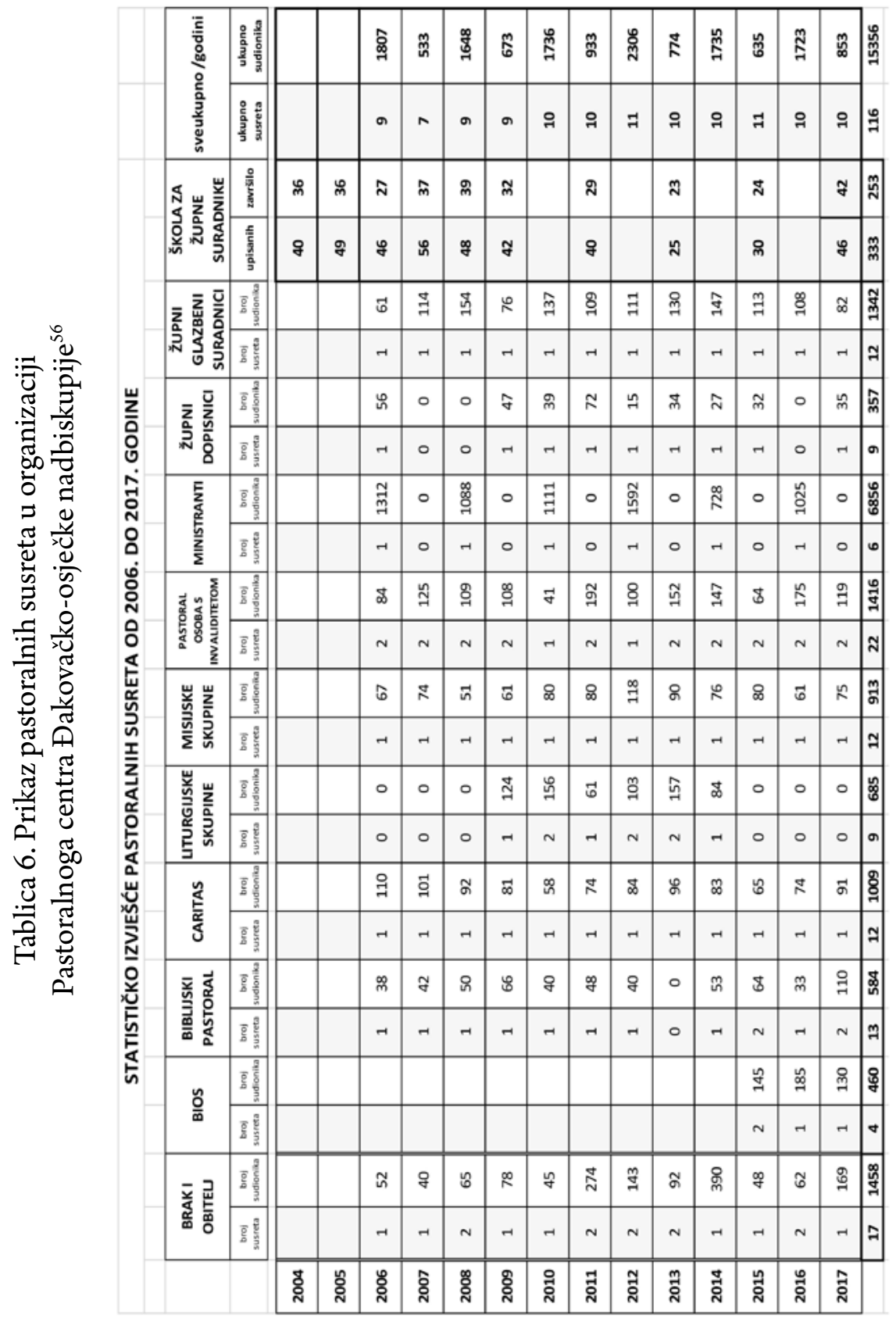

${ }^{56}$ Usp. Arhiv Pastoralnog centra Đakovačko-osječke nadbiskupije, statički podatci u elektroničkom obliku - mapa Susreti na nadbiskupijskoj razini. 
Budući da je na Drugoj biskupijskoj sinodi đakovačkoj i srijemskoj uočena veličina i dubina krize vjere, pastoralni kairos zahtijevao je najsnažnije usmjerenje na evangelizacijsko i misionarsko djelovanje. Crkva đakovačka i srijemska, posredstvom ureda i povjerenstava u sastavu Pastoralnoga centra, napose župnih zajednica, nastojala je i nastoji biti svakom vjerniku, kako kaže papa Franjo, svjetionik, luka, baklja, poljska bolnica, obitelj i kvasac. ${ }^{57}$ Koliko (je) ona to uspijeva(la) biti, ovisi(lo) (je)o postojećoj infrastrukturi, posebice na župnoj razini. Nedostatak infrastrukture u personalnom smislu i neuspjeh da se vjernike laike snažnije i kvalitetnije uključi u evangelizacijsko poslanje Crkve, napose da ih se učini subjektom, a ne samo objektom evangelizacije, poteškoća je koja prati sinodsko događanje od početka do danas. ${ }^{58}$

Iz analize susreta na nadbiskupijskoj razini na kojima je sudjelovalo od 2006. do 2018. godine 15356 osoba uočava se kako se u pojedinim područjima pastoralnoga djelovanja broj sudionika smanjuje, a u nekima se povećava. Razlozi povećanja ili smanjenja uglavnom se mogu svesti na dvije razine: ondje gdje je voditelj ureda ili povjerenik profesionaliziran i stručan broj sudionika na nadbiskupijskim susretima povećava se ili je ustaljen, a gdje je voditelj ureda ili povjerenik imenovan na temelju osobnog afiniteta, bez stručnosti, nerijetko se broj sudionika na nadbiskupijskim susretima smanjuje ili stagnira. Rezultate je vrlo lako uočiti ako se usporedi tablica 6. (prikaz pastoralnih susreta u organizaciji Pastoralnoga centra Đakovačkoosječke nadbiskupije) s tablicom 7. (prikaz profesionalne i stručne osposobljenosti pojedinih voditelja ureda i povjerenika u pastoralnom centru Đakovačko-osječke nadbiskupije).

Analizom dostupnih podataka iz formulara kanonskih vizitacija ${ }^{59} \mathrm{i}$ njihovih zapisnika u posljednjih deset godina, odnosno od proglašenja Izjava i odluka Druge biskupijske sinode đakovacke i srijemske, utvrđeno je da je na razini nadbiskupije, regionalnoj razini te dekanatskoj ${ }^{60}$ uz poticaj središnjega koordinacijskoga ureda organizirano više od dvjesto susreta.

${ }^{57}$ Usp. FRANJO, Amoris laetitia, Zagreb, 2016., 291-292., 222-223.

${ }^{58}$ Usp. Ti si Krist - za nas i za sve ljude, br. 8.

${ }^{59}$ Usp. Arhiv nadbiskupskog ordinarijata Đakovo, Fond kanonske vizitacije 2008-2018., bb. Za navedene godine analizirano je sveukupno 3653 stranice podataka.

${ }^{60} \mathrm{Za}$ nadbiskupijske i regionalne susrete podatak je točan, međutim za dekanatske susrete podatak nije točan jer velik broj dekanatskih susreta nije evidentiran ni u zapisnicima kanonskih vizitacija ni u središnjem koordinacijskom uredu pastoralnoga centra nadbiskupije zbog neredovitoga slanja i izvješća o održanim susretima. U zapisnicima kanonskih vizitacija također je vrlo lako uočljiva implementacija sinodskih dokumenta ili zaključaka u životu svake župne zajednice. Zapisnici kanonskih vizitacija usredotočeni su na događanja u župnim zajednicama, tako se vrlo lako navedeno može iščitati, prepoznati, vidjeti, prosuditi, a onda i zaključiti na koji način djelovati kako bi se dosadašnja praksa mogla poboljšati. 
Tablica 7. Prikaz profesionalne i stručne osposobljenosti pojedinih voditelja ureda i povjerenika u pastoralnom centru Đakovačko-osječke nadbiskupije

\begin{tabular}{|c|c|}
\hline Odjel / ured / povjerenstvo & Osposobljenost voditelja/povjerenika \\
\hline Ured za promicanje socijalnog nauka Crkve & stručnost \\
\hline Ured za vjernička društva & $50 \%$ stručnost, $50 \%$ afinitet \\
\hline Ured za pastoral braka i obitelji & stručnost \\
\hline Djelo za zvanja & osobni afinitet \\
\hline $\begin{array}{l}\text { Pastoral branitelja i stradalnika } \\
\text { Domovinskog rata }\end{array}$ & osobni afinitet \\
\hline Biblijski pastoral & osobni afinitet \\
\hline Ured za promicanje ekumenizma & stručnost \\
\hline Pastoral osoba s invaliditetom & osobni afinitet \\
\hline Pastoral ministranata & osobni afinitet \\
\hline Ured za pastoral mladih & osobni afinitet \\
\hline Trajna formacija župnih kateheta & stručnost \\
\hline Ured za pastoral studenata & osobni afinitet \\
\hline Župne liturgijske skupine & osobni afinitet \\
\hline Župne misijske skupine & osobni afinitet \\
\hline Karitativna djelatnost & stručnost \\
\hline Ured za crkvenu glazbu & stručnost \\
\hline Župni dopisnici & stručnost \\
\hline Pastoral tradicijske kulture & osobni afinitet \\
\hline Pastoral intelektualaca & osobni afinitet \\
\hline Pastoral liječnika & osobni afinitet \\
\hline Pastoral bolesnika & osobni afinitet \\
\hline Pastoral Roma & osobni afinitet \\
\hline Pastoral Slovaka & osobni afinitet \\
\hline Pastoral za ovisnosti & osobni afinitet \\
\hline Pastoral zatvorenika & osobni afinitet \\
\hline Ukupno 25 voditelja ureda/povjerenika & $\begin{array}{c}17 \text { osobni afinitet, stručnost } 7, \\
\text { u istom uredu } 1 \text { osoba, stručnost/ } 1 \text { osoba } \\
\text { osobni afinitet. }\end{array}$ \\
\hline
\end{tabular}




\section{Tablica 8.}

\begin{tabular}{|c|c|}
\hline \multicolumn{2}{|c|}{ Prema zapisnicima kanonskih vizitacija } \\
\hline $\begin{array}{c}\text { 201 susret - broj sudjelovanja - } \\
\text { nadbiskupijski, regionalni, dekanatski }\end{array}$ & Broj župa (146) \\
\hline 0 & $18(26,28 \%)$ \\
\hline $1-5$ & $15(10,27 \%)$ \\
\hline $6-10$ & $31(21,23 \%)$ \\
\hline $11-20$ & $55(37,67 \%)$ \\
\hline $21-50$ & $25(17,12 \%)$ \\
\hline $51-100$ & $2(1,37 \%)$ \\
\hline $101-150$ & 0 \\
\hline
\end{tabular}

Zapisnici kanonskih vizitacija pokazuju kako su na župama vrlo malo i slabo zaživjeli sinodski dokumenti, odnosno Izjave i odluke Druge biskupijske sinode đakovačke i srijemske. Svega 1,37\% župa poslalo je na 50\% sadržaja formativnoga karaktera na nadbiskupijskoj, regionalnoj i dekanatskoj razini župne suradnike ili animatore pojedinih pastoralnih područja u župnim zajednicama. Činjenica da samo $18,49 \%$ župa relativno aktivno sudjeluje na formativnim susretima, a $81,51 \%$ župa slabo, vrlo slabo ili gotovo nikako ne sudjeluje, nužno nameće mnogobrojna pitanja na koja trebaju odgovoriti ne samo župnici nego i osobe koje su zadužene za pojedina pastoralna područja u Nadbiskupiji, posebice najodgovorniji za njezin cjelokupni život i rad.

Zaključci i ujedno prijedlozi za poboljšanje pastoralne prakse koji se nameću nakon analize pastoralnih nastojanja:

- Izjave i odluke Druge biskupijske sinode đakovacke i srijemske u većoj mjeri zaživjele su u 30\% župnih zajednica Đakovačko-osječke nadbiskupije.

- Jedan od uzroka, razloga zašto su sinodski zaključci zaživjeli u 30 \% župnih zajednica Đakovačko-osječke nadbiskupije treba tražiti i u krizi identiteta svećenika evangelizatora. U tom kontekstu slobodno se može ustvrditi kako dokument Ti si Krist - za nas i za sve ljude za značajniji dio svećenika/župnika Đakovačkoosječke nadbiskupije nije magna carta pastoralnoga djelovanja. ${ }^{61}$

${ }^{61}$ Takav zaključak utemeljen je na sadržaju te analizi 3., 6. i 8. tablice. 
- Getoizacija Crkve tijekom komunizma i sprječavanje Crkve u njezinu pastoralno-katehetskom poslanju utjecali su na mentalitet vjernika Đakovačko-osječke nadbiskupije. Posljedice komunističkoga režima i danas se osjećaju, a izravno su utjecale na značajnije i snažnije (ne)prihvaćanje i (ne)uključivanje u sinodska i postsinodska događanja. Naime vjernik je na ovim prostorima nakon komunističke ideologije u velikoj mjeri prožet vjerskom nezainteresiranošću, vjerskim indiferentizmom, naglašenim vjerskim neznanjem, nesuživljenošću s Crkvom, klerikalizmom, napose pastoralno-katehetskom pasivnošću.

- Na svećeničko i vjerničko (ne)prihvaćanje sinodskih zaključaka i Izjava i odluka Druge biskupijske sinode đakovačke i srijemske u velikoj mjeri utječe i današnja kultura izbora, selfie-kultura, diktatura relativizma, materijalizam, ekstremni sekularizam, anarhizam, ateizam, subjektivizam, individualizam i autoreferencijalnost.

- Dokument Ti si Krist - za nas i za sve ljude zahtijeva i pretpostavlja novi zanos, novi žar i zamahu evangelizacijskom, pastoralnom i katehetskom djelovanju jednako kod svećenika i vjernika. ${ }^{62}$

- Knjiga sinode računa ne samo na sustavnu permanentnu formaciju svećenika evangelizatora, upoznavanje sinodskih dokumenta nego podrazumijeva i vid preinake u svećenikovoj teološko-pastoralno-duhovnoj formaciji, posebice $u$ kontekstu prepoznavanja znakova vremena u Crkvi i društvu.

- Analiza pastoralnih nastojanja ukazuje i na potrebu veće stručnosti i osposobljenosti, napose profesionalizacije i specijalizacije voditelja ureda, povjerenika, osoba kojima je povjereno jedno od pastoralnih područja. Nerijetko su voditelji ureda i povjerenici, tajnici ureda i povjerenstava pastoralnih područja osobe kojima je zbog osobnih sklonosti povjereno pojedino pastoralno područje. Velika većina voditelja ureda, povjerenika, tajnika uz jednu ili nekoliko drugih službi povjereno područje nastoje ostvariti unatoč tomu što često vremenski i profesionalno nisu u mogućnosti dovoljno se i kvalitetno angažirati.

- Za kvalitetniji, strukturiraniji i sveobuhvatniji pastoralni rad, prožet kapilarnim pristupom, potrebna je veća, snažnija i bolja pastoralno-personalno-profesionalna infrastruktura, posebice na župnoj razini.

- Uočava se potreba snažnijega uključivanja vjernika laika u vođenje pojedinih ureda i povjerenstava u sklopu Pastoralnoga centra Đakovačko-osječke nadbiskupije, posebice veća angažiranost i uključenost vjernika laika u život, animiranje, vođenje, koordiniranje, angažiranost u vlastitim župnim zajednicama. ${ }^{63}$

${ }^{62}$ Takav zaključak utemeljen je na sadržaju te analizi 3., 6. i 8. tablice.

${ }^{63}$ Zbog ograničenosti opsega rada autor nije u mogućnosti prikazati sve kako bi u potpunosti svaka tvrdnja bila potkrijepljena sveobuhvatnim činjenicama i analizama. No kao koordinator na temelju 
- Teologe laike nakon pružene specijalizacije i profesionalne osposobljenosti potrebno je u većem broju zaposliti i uključiti u pojedine vidove pastoralnoga i katehetskoga života i rada na nadbiskupijskoj, posebice među župnoj i župnoj razini. Uključivanjem vjernika laika kroz dimenziju profesionaliziranosti omogućilo bi se kvalitetnije ostvarivanje sinodskih zaključaka, izjava i odluka na svim razinama, napose na župnoj razini.

- Iz analize prikaza pojedinih (ne)ostvarenja Knjige sinode primjetna je nužna promjena pastoralnoga pristupa, novih načina i metoda u pastoralnom radu i djelovanju.

- Postsinodsko vrijeme zatečeno je pluralističkom demokracijom u kojoj nerijetko postoji ne samo izostanak religioznoga jezika, života i djelovanja nego i tiho napuštanje kršćanstva. Izjave i odluke Druge biskupijske sinode đakovačke i srijemske susreću se s agresivnim stvaranjem novih oblika individualne religioznosti, duhovnosti bez osobne vjere, religije bez Boga.

- Sinodska nastojanja i odluke nužno je promatrati u duhu vremena u kojem sveopća i mjesna Crkva žive i nalaze se. Danas na pastoralno djelovanje te provođenje sinodskih zaključaka utječe loše ekonomsko, migracijsko, posebice demografsko stanje u Nadbiskupiji. ${ }^{64}$

\section{Umjesto zaključka}

Sinodske smjernice nisu snažnije i značajnije zaživjele u životu Crkve đakovačkoosječke. Sinoda je postala više događaj, a željelo se da postane sustavno događanje. Snaga »plamenih jezika « (usp. Iz 5, 24) pretvorila se ili ostala »stijenje što tek tinja « (usp. Iz 42, 3; Mt 12, 20). Crkvi đakovačko-osječkoj potrebni su sustavni, snažno infrastrukturno profesionalizirani, isusovsko hrabri iskoraci u evangelizacijskom, pastoralnom i katehetskom radu. No unatoč svim poteškoćama i nedostatcima Đakovačko-osječka nadbiskupija i njezin život nezamislivi su bez sinodskih dokumenta, posebice Izjava i odluka Druge biskupijske sinode dakovačke i srijemske. Novonastale okolnosti ne bismo trebali gledati kao kamen spoticanja u provođenju već donesenih planova i ideja, nego kao dodatan poticaj za osmišljavanje novih načina i obrazaca kojima ćemo spasenjsku poruku približiti vjernicima. Na temelju

analize navedenoga, ali i mnogih drugih podataka koji u radu nisu spomenuti, npr. zapisnici sjednica povjerenstava, vijeća, koordinacija, svaku je tvrdnju utemeljio na analizi postojećega činjeničnoga stanja.

${ }^{64}$ Đakovačko-osječka nadbiskupija jedna je od partikularnih Crkava iz koje je posljednjih deset godina najviše stanovništva iselilo, napustilo domove i otišlo zbog ekonomskih razloga u bogatije zemlje Europske unije. Usp. Siromaštvo i demografsko stanje u Slavoniji, Baranji i Srijemu. Korizmena poslanica slavonskih biskupa, Osijek - Požega, 2016., 2-19. 
podataka dobivenih iz izvještaja s kanonskih vizitacija i podataka u arhivi Pastoralnoga centra možemo reći kako nije došlo do velikoga odjeka i ostvarenja svega onoga što nam dokument Ti si Krist - za nas iza sve ljude donosi kao hodogram pastoralnoga djelovanja u Nadbiskupiji. Ipak, dokument ostaje baština mjesne Crkve te je istodobno i polazište za svako daljnje djelovanje svih sudionika na svim područjima pastorala u Nadbiskupiji te kamen temeljac i putokaz za nastavak pastoralnoga djelovanja. Kako bi se to dogodilo, uz dimenziju osluškivanja događanja u društvu i Crkvi, potrebno je cjelokupno pastoralno i katehetsko djelovanje osuvremenjivanjem sinodskih zaključaka prožeti Kristovom jednostavnošću i privlačnošću. 


\author{
THE ANALYSIS OF PASTORAL EFFORTS AFTER \\ THE PROMULGATION OF THE DOCUMENT \\ YOU ARE CHRIST - FOR US AND FOR ALL PEOPLE. \\ STATEMENTS AND DECISIONS OF THE SECOND \\ SYNOD OF THE DIOCESE OF ĐAKOVO AND SRIJEM.
}

\title{
Stanislav ŠOTA*
}

Summary: Following the first democratic elections, after forty-five years of the totalitarian communist regime, and during the Croatian War for Independence and the Greater Serbian aggression in the 1990s, the Church in the Diocese of Đakovo and Srijem has significantly changed its $\gg$ face and reverse $\ll$, its circumstances and ambiance. The Second Synod was an event and an occurrence of the Holy Spirit and concrete man. The decisions, statements, and provisions of the Diocesan Synod were meant to become the daily life of the particular Church. The Book of the Synod $\gg Y o u$ are Christ - for us and for all people« was published in 2008. Ten years after the publication of the Statements and Decisions of the Second Synod of the Diocese of Đakovo and Srijem, a review of pastoral efforts over the decade shows that the Statements and Decisions of the Second Synod of the Diocese of Đakovo and Srijem have been realized to a greater extent in only 30\% of the parish communities of the Archdiocese of Đakovo-Osijek. The crisis of the evangelizing zeal of presbyters and parish priests, the crisis of their identity, and the formation that largely ignored the synodal conclusions, the communist legacy which left behind religious indifference, non-coexistence with the Church, clericalism, passivity, and especially today's culture of choice and the dictatorship of relativism are the fundamental and most common causes why the document $\gg$ You are Christ - for us and for all people $\ll$ is not the magna carta of pastoral work in the Archdiocese of Đakovo-Osijek. The analysis of pastoral efforts points to the need for greater expertise and qualifications, especially for the professionalization and specialization of the heads of offices, commissioners, and persons entrusted with one of the pastoral areas. Most heads of offices, commissioners, and secretaries, that are carrying out one or more other duties, try to accomplish the entrusted area without enough opportunities to apply themselves appropriately. There is a greater and stronger need to involve the laity in running certain offices and commissions. If the local Church wants to implement the synodal documents more effectively into the everyday life, it must find the strength to include the lay faithful into the pastoral life and

\footnotetext{
* Asst. Prof. Stanislav Šota, Ph. D., Catholic Faculty of Theology in Đakovo, J. J. Strossmayer University of Osijek, P. Preradovića St 17, P. O. box 54, 31400 Đakovo, Croatia, stanislav.sota@os.t-com.hr
} 
work of the Archdiocese. There is a need for a significant change of pastoral approaches, forms and methods used in pastoral work and activities. The Synod has become more of a one-time event, and it was meant to be a systematic occurrence. The power of the $\gg$ tongues of fire « (cf. Isaiah 5:24) has become or remained $\gg$ a smoldering wick « (cf. Isaiah 42: 3; Matthew 12:20). The Church of Đakovo-Osijek needs to take systematic, strongly infrastructurally professionalized, Jesus-like and courageous steps forward. Despite the difficulties and shortcomings, the Archdiocese of Đakovo-Osijek and its life are unimaginable without the synodal documents, that is, the Statements and Decisions of the Second Synod of the Diocese of Đakovo and Srijem.

Keywords: Second Synod of the Diocese of Đakovo and Srijem, synod, analysis, pastoral successes and failures, a need for a change. 